\title{
First molecular detection of co-infection of honey bee viruses in asymptomatic Bombus atratus in South America
}

\author{
Reynaldi, FJ. ${ }^{a, b, *}$, Sguazza, GH. ${ }^{a}$, Albicoro, FJ. ${ }^{a}$, Pecoraro, MR. ${ }^{a}$ and Galosi, CM. ${ }^{a, c}$ \\ ${ }^{a}$ Department of Virology, Faculty of Veterinary Sciences, National University of La Plata, 60 \& 118 , \\ La Plata CP 1900, Buenos Aires, Argentina \\ ${ }^{b}$ National Research Council - CONICET, 8 n. 1467 (62 \& 63), La Plata CP 1900, Buenos Aires, Argentina \\ ${ }^{c}$ Scientific Research Commission - CIC - PBA, 10 \& 526, La Plata CP1900, Buenos Aires, Argentina \\ e-mail:freynaldi@yahoo.com \\ Received April 12, 2012 - Accepted October 2, 2012 - Distributed November 29, 2013
}

(With 2 figures)

\begin{abstract}
Pollination is critical for food production and has the particularity of linking natural ecosystems with agricultural production systems. Recently, losses of bumblebee species have been reported worldwide. In this study, samples from a commercial exploitation of bumblebees of Argentina with a recent history of deaths were studied using a multiplex PCR for the detection of the honey bee viruses most frequently detected in South America. All samples analysed were positive for co-infections with Deformed wing virus, Black queen cell virus and Sacbrood virus. This is the first report of infection of Bombus atratus with honey bee viruses. A better understanding of viral infections in bumblebees and of the epidemiology of viruses could be of great importance as bumblebees can serve as possible viral reservoirs, resulting in pathogen spillover towards honey bees and native bumblebees.
\end{abstract}

Keywords: Argentine, bumblebee, multiplex PCR.

\section{Primeira detecção molecular de co-infecção de vírus de abelhas em Bombus atratus assintomática na América do Sul}

\section{Resumo}

A polinização é essencial para a produção de alimentos e tem como particularidade a conexão entre os ecossistemas naturais com sistemas de produção agrícola. Recentemente, as perdas de espécies de bumblebee em todo o mundo têm sido relatadas. Neste trabalho, amostras de uma exploração comercial de bumblebee da Argentina, com recente história de mortes foram estudadas utilizando uma Multiplex PCR para a detecção de vírus de abelha mais frequentemente detectados na América do Sul. Todas as amostras analisadas foram positivas para as co-infecções com Deformed wing virus, Black queen cell viruses e Sacbrood virus. Este trabalho descreve o primeiro relato de infecção de Bombus atratus com vírus de abelhas. Uma melhor compreensão das infecções virais em bumblebee e da epidemiologia dos vírus poderia ser de grande importância, uma vez que tais abelhas podem servir como reservatório viral, com possível repercussão tanto na produtividade de abelhas melíferas como afetando-as diretamente.

Palavras-chave: Argentina, bumblebee, PCR multiplex.

\section{Introduction}

Pollination is due mainly to the action of different insects, such as the bumblebee and the honey bee. This process is critical for food production and has the particularity of linking natural ecosystems with agricultural production systems (Klein et al., 2007). Any of the members of the 240 species of the bee genus Bombus is considered a bumblebee (Abrahamovich and Díaz, 2001). Bumblebees are social insects characterised by black and yellow body hairs often in bands, although some species, such as Bombus atratus, are entirely black. In Argentina, only eight species have been described and Bombus atratus, Bombus morio and Bombus bellicosus display the most widespread distribution. However, Bombus atratus is the most abundant, probably because it is tolerant to different climates and altitudes (Plischuk et al., 2009). In recent years, bumblebees have been increasingly used in agriculture as pollinators because they can pollinate plant species that other pollinators cannot, by using a technique known as buzz pollination. For example, bumblebee colonies are often placed in tomato production greenhouses, because the frequency of buzzing exhibited by a bumblebee releases tomato pollen effectively. As a consequence, bumblebees are transported worldwide resulting in pathogen spillover from bumblebees that escape from the greenhouse facilities (Colla et al., 2006). Differ- 
ent bee pathogens have been detected in bumblebees. These include the honey bee parasite Nosema ceranae (Plischuk et al., 2009) and some viruses like Acute bee paralysis virus (ABPV) (Bailey and Gibbs, 1964), Kashmir bee virus (KBV) (Ward et al., 2007) and Deformed wing virus (DWV), reported in Bombus terrestris and Bombus pascuorum in Germany in 2006 (Genersch et al., 2006). In recent years, losses of bumblebee species have been reported worldwide (Williams and Osborne, 2009) and, in this sense, Plischuk et al. (2009) described the presence of Nosema ceranae in bumblebees in Argentina.

Recently, we were alerted by a bumblebee producer that several colonies in Buenos Aires Province (Argentina) were dying. The bumblebee sample belonged to a commercial endeavour dedicated to producing colonies for pollination. These colonies were developed in an isolated place in an attempt to avoid contact with chemicals. A first study indicated that all samples of these bumblebees were negative for Varroa destructor mites and Nosema ceranae. Therefore, the aim of this study was to investigate whether honey bee viruses could be affecting those bumblebee colonies.

\section{Materials and Methods}

Twenty samples (consisting of 40 adult worker bumblebees each) from a total of 210 colonies of bumblebees used as pollinators in greenhouse tomato production in Buenos Aires Province were used in this study. Samples were taken directly from colonies affected with mortality but without specific symptoms. Ten samples were collected in April 2011 and another ten in June 2011 in order to be screened for the detection of the honey bee viruses most frequently detected in South America. All samples were stored at $-70{ }^{\circ} \mathrm{C}$ until they were processed. Fifteen bumblebees randomly selected from each sample were crushed in stomacher bags with $2 \mathrm{~mL}$ of phosphatebuffered saline. After homogenisation, the samples were centrifuged for $15 \mathrm{~min}$ at $1500 \mathrm{xg}$ and total RNA was extracted using $500 \mu \mathrm{L}$ of Trizol reagent and mixed with $500 \mu \mathrm{L}$ of the supernatant previously obtained. The mixture was extracted with $220 \mu \mathrm{L}$ of chloroform. After centrifugation at $12000 \mathrm{xg}$ for $10 \mathrm{~min}$, the RNA contained in the aqueous solution was precipitated by adding an equal volume of isopropanol. The precipitated RNA was collected by centrifugation at $12000 \mathrm{xg}$ for $10 \mathrm{~min}$, washed with $70 \%$ ethanol and dissolved in $50 \mu \mathrm{L}$ of RNase-free water. Then, $5 \mu \mathrm{L}$ (approximately $3 \mu \mathrm{g}$ ) of total RNA extracted was used for synthesis of complementary DNA (cDNA). This reaction was carried out using the enzyme of the Moloney Murine Leukemia Virus (Promega Madison, Wisconsin. USA) under conditions specified by the supplier and using $40 \mathrm{ng}$ of a mixture of random primers. A multiplex polymerase chain reaction (mPCR) developed was carried out for the detection of each virus. For amplification of Israeli acute paralysis virus (IAPV), a previously published primer pair (Reynaldi et al., 2011) was used and for the other six viruses, specific primer pairs were designed (Table 1). The $\mathrm{mPCR}$ reaction was performed in a final volume of $25 \mu \mathrm{L}$. Then, $5 \mu \mathrm{L}$ of cDNA was added to a reaction mixture containing $2.5 \mu \mathrm{L}$ of $10 \mathrm{X}$ buffer $(75 \mathrm{mM}$ Tris$\mathrm{HCl} \mathrm{pH} \mathrm{8.8,} 20 \mathrm{mM}\left(\mathrm{NH}_{4}\right)_{2} \mathrm{SO}_{4}, 0.01 \%$ Tween 20), $0.75 \mu \mathrm{L}$ of $10 \mathrm{mM}$ dNTp mixture, $1.5 \mu \mathrm{L}$ of $\mathrm{MgCl}_{2}$, $0.5 \mu \mathrm{M}$ of each primer, $13.75 \mu \mathrm{L}$ of RNase-free water and $0.5 \mu \mathrm{L}(2.5 \mathrm{U})$ of Taq DNA polymerase. Two negative $\mathrm{mPCR}$ controls were used: 1) sample prepared by excluding the cDNA from the reaction and 2) negative samples from honey bees previously analysed in this laboratory. Positive controls were taken from honey bee positive samples detected in previous studies except for

Table 1 - Primers used for the detection of honey bee viruses in Bombus atratus. AIKV: universal primer to amplify ABPV (Acute bee paralysis virus), IAPV (Israeli acute paralysis virus) and KBV (Kasmir bee virus). CBPV: Chronic bee paralysis virus, BQCV: Black queen cell virus, DWV: Deformed wing virus, SBV: Sacbrood bee virus.

\begin{tabular}{llccc}
\hline & Sequence & Orientation & Target & Amplicon length (bp) \\
\hline AIKVf & GGTGCCCTATTtAGGGTGAGGA & Sense & ABPV - IAPV - KBV & 460 \\
ABPVr & ACTACAGAAGGCAATGTCCAAGA & Antisense & ABPV & 158 \\
IAPVr & GGGAGTATTGCTTTCTTGTTGTG & Antisense & IAPV & 641 \\
KBVr & TGCACGGGAAGTATAAATAATTCT & Antisense & KBV & 269 \\
DWVf & TGGTCAATTACAAGCTACTTGG & Sense & DWV & \\
DWVr & TAGTTGGACCAGTAGCACTCAT & Antisense & & 342 \\
SBVf & CGTAATTGCGGAGTGGAAAGATT & Sense & SBV & 774 \\
SBVr & AGATTCCTTCGAGGGTACCTCATC & Antisense & & \\
CBPVf & AACCTGCCTCAACACAGGCAAC & Sense & CBPV & \\
CBPVr & ACATCTCTTCTTCGGTGTCAGCC & Antisense & & 536 \\
BQCVf & CTTTATCGAGGAGGAGTTCGAGT & Sense & BQCV & \\
BQCVr & GCAATAGATAAAGTGAGCCCTCC & Antisense & & \\
\hline
\end{tabular}


KBV that has still not been found in Argentina. These PCR products were opportunely sequenced and alignment was performed with sequences available in GenBank. The PCR was carried out using a thermal protocol consisting of one denaturalisation cycle of $5 \mathrm{~min}$ at $95^{\circ} \mathrm{C}$, followed by 40 amplification cycles $\left[30 \mathrm{~s}\right.$ at $95^{\circ} \mathrm{C}$, $30 \mathrm{~s}$ at $53^{\circ} \mathrm{C}$, extension of $60 \mathrm{~s}$ at $\left.72^{\circ} \mathrm{C}\right]$ and a final extension of $5 \mathrm{~min}$ at $72{ }^{\circ} \mathrm{C}$. The amplification products were analysed by agarose gel electrophoresis and ethidium bromide staining. The molecular sizes of the fragments were compared with those of a molecular weight marker of 100-1500 bp (Fermentas, Tecnolab, Bs As, Argentina). The mPCR products were purified using a gel extraction kit (Wizard ${ }^{\circledR}$ SV Gel \& PCR Clean Up, Promega Madison, Wisconsin,USA) and sequenced (Biotechnology Resource Center, University of Cornell, Ithaca, USA). The sequences were analysed using Basic Local Alignment Search Tool (BLAST) software.

\section{Results and Discussion}

All the samples of bumblebee analysed were positive for co-infections with DWV, BQCV and SBV (Figure 1), which visually run the same as our the positive controls (Figure 2). Co-infections of these three viruses have already been detected in forager honey bees $(16,9 \%)$ and only $1.5 \%$ in pollen samples (Singh et al., 2010). Our samples tested negative for $\mathrm{ABPV}$ and $\mathrm{KBV}$ viruses, commonly associated with varroa infestation in honey bees (de Miranda et al., 2004), and for CBPV and IAPV. BLAST results confirmed the identity of the mPCRamplified sequences. Specifically, DWV showed $99 \%$ of

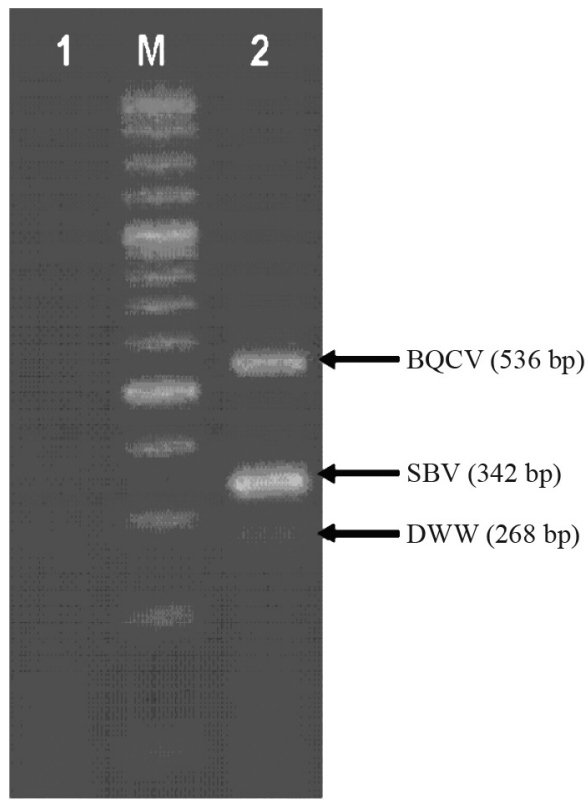

Figure 1 - Agarose gel electrophoresis of mPCR products of bumblebee samples. Lane M: molecular weight marker (100-1500 bp). Lane 1: negative control, Lane 2: positive amplification for Deformed Wing Virus (DWV), Sacbrood Bee Virus (SBV) and Black Queen Cell Virus (BQCV).

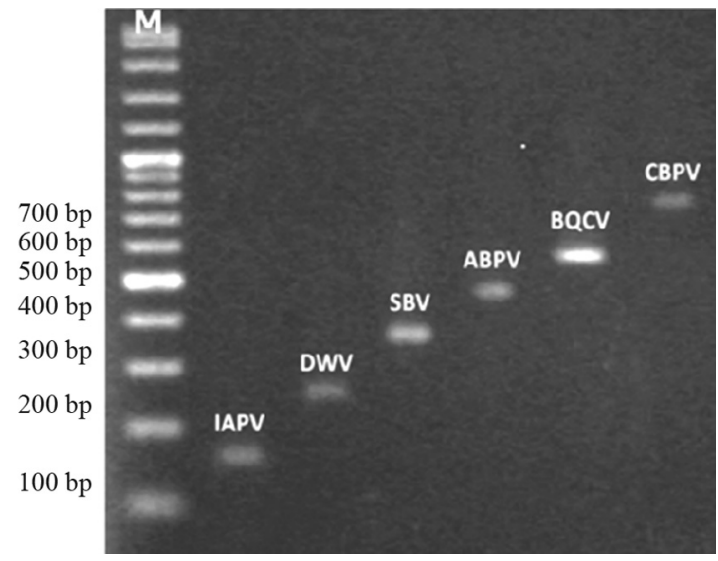

Figure 2 - Agarose gel electrophoresis of $\mathrm{mPCR}$ for positive controls of each virus. From left to right: 158 bp (IAPV), 269 bp (DWV), 342 bp (SBV), 460 bp (ABPV), 536 bp (BQCV), 774 bp (CBPV). M: molecular weight marker (100-1500 bp).

homology with the DQ224309 sequence, BQCV 98\% of homology with the GU108221 sequence and SBV 99\% of homology with the AY152712 sequence. Genersch et al. (2006) found DWV infection in other bumblebees correlated with wing deformities, suggesting a broader host specificity of this virus and a switch to a new host species. In this way, they explained the perfect correlation between DWV infection and wing deformities. In contrast, our most relevant finding was the detection of DWV, without signs of wing deformities. All these bee viruses have been widely detected in Buenos Aires province (Reynaldi et al., 2010 and unpublished data). Furthermore, in other South American countries, some honeybee viruses have been detected, such as BQCV, DWV and ABPV in Brazil (Teixeira et al., 2008) and DWV, $\mathrm{SBV}, \mathrm{BQCV}, \mathrm{ABPV}$ and CBPV in Uruguay (Antúnez et al., 2006). This suggests that DWV could have switched from honey bees to bumblebees in Argentina some time ago. In this way, Li et al. (2011) suggest that the high mutation rate of the RNA virus in conjunction with the geographic proximity between the bumblebees and honey bees and the high contact rate of foragers at food sources (pollen) would provide high adaptability for host shift of DWV in nature. Even more, we detected BQCV and SBV in the samples studied. SBV affects the brood of honey bees, and it occurs mostly as a mild infection, which kills only a few larvae, but it can be more severe. Few hives die out as a direct result of it, but many are weakened to an extent where they succumb to other threats. This situation couldoccur with similar effects on the colonies of bumblebees, causing their death. In this way, other authors suggest the importance of flowers in the transmition of several pathogens, such as Crithidia bombi and Nosema bombi (Colla et al., 2006) and honey bee viruses (Singh et al., 2010).

In summary, the findings described here demonstrate the first report of infection of Bombus atratus with DWV, 
SBV and BQCV in commercial bumblebee colonies of Argentina. These results indicate that the knowledge of viral infections in bumblebees is of great importance because they can serve as possible viral reservoirs, resulting in pathogen spillover towards honey bees and native bumblebees. A better understanding of the epidemiology of viruses is vital to know the dynamics of virus outbreaks and may shed light on the current crisis of the worlds pollinators.

\section{Acknowledgments}

We thank Mr. C. Leguizamón and Ms A. Conde for the reception of samples. FJR, CMG and MRP are Career Researchers of the National Research Council, Scientific Research Commission (CIC- PBA) and National University of La Plata (UNLP), respectively. GHS and MAT are recipients of a scholarship from UNLP and CIC-PBA. This work was funded by grants from the National University of La Plata (Argentina) and CIC-PBA.

\section{References}

ABRAHAMOVICH, AH. and DÍAZ, NB., 2001. Distribución geográfica de las especies del género Bombus latreille (Hymenoptera, Apidae) en Argentina. Rev. Bras. Entomol. vol. 45, p. 23-36.

ANTÚNEZ, K., DALESSANDRO, B., CORBELLA, E., RAMALLO, G. and ZUNINO, P., 2006. Honeybee viruses in Uruguay. J Invertebr Pathol, vol. 93, p. 67-70.

BAILEY, L. and GIBBS, AJ., 1964. Acute infection of bees with paralysis virus. J. Insect. Pathol, vol. 6, 395-407.

COLLA, SR., OTTERSTATTER, MC., GEGEAR, RJ. and THOMSON, JD., 2006. Plight of the bumble bee: pathogen spillover from commercial to wild populations. Biol. Conserv, vol. 129, p. 461-467.

DE MIRANDA, JR., DREBOT, M., TYLER, S., SHEN, M., CAMERON, CE., STOLTZ, DB. and CAMAZINE, SM., 2004. Nucleotide sequence of Kashmir bee virus and comparison with acute bee paralysis virus. J. Gen. Virol. vol. 85, p. 2263-2270.

GENERSCH, E., YUE, C., FRIES, I. and DE MIRANDA, JR., 2006. Detection of Deformed wing virus, ahoney bee viral pathogen, in bumble bees (Bombus terrestris and Bombus pascuorum) with wing deformities. J. Invertebr. Pathol, vol. 91, p. 61-63.

KLEIN, AM., VAISSIERE, JH., CANE, JH., STEFFANDEWENTER, I., CUNNINGHAM, SA., KREMEN, C. and TSCHARNTKE, T., 2007. Importance of pollinators in changing landscapes for world crops. Proc. R. Soc. Lond. B. Biol. Sci. vol. 274, p. 303-313.

LI, J., PENG, W., WU, J., STRANGE, JP., BONCRISTIANI, H. and CHEN, Y., 2011. Cross-Species Infection of Deformed Wing Virus Poses a New Threat to Pollinator Conservation. J. Econ. Entomol., vol. 104, no. 3, p. 732-739.

PLISCHUK, S., MARTÍN-HERNÁNDEZ, R., PRIETO, L., LUCIA, M., BOTÍAS, C., MEANA, A., ABRAHAMOVICH, A., LANGE, C. and HIGES, C., 2009. South American native bumblebees (Hymenoptera: Apidae) infected by Nosema ceranae (Microsporidia), an emerging pathogen of honeybees (Apis mellifera). Env. Microbiol. Rep. vol. 1, p. 131-135.

REYNALDI, FJ., SGUAZZA, GH., PECORARO, MR., TIZZANO, MA. and GALOSI, MC., 2010. First report of viral infection that affect argentine honeybees. Env. Microbiol. Rep. vol. 2, p. 749-751.

REYNALDI, FJ., SGUAZZA, GH., TIZZANO, MA., FUENTEALBA, N., GALOSI, CM. and PECORARO, MR., 2011. First report of Israeli acute paralysis virus in asymptomatic hives of Argentina. Rev Arg. Microbiol. vol. 43, p. $84-86$.

SINGH, R., LEVITT, AL., RAJOTTE, EG., HOLMES, EC., OSTIGUY, N., VANENGELSDORP, D., LIPKIN, WI., DEPAMPHILIS, CW., TOTH, AL. and COX-FOSTER, DL., 2010. RNA Viruses in Hymenopteran Pollinators: Evidence of Inter-Taxa Virus Transmission via Pollen and Potential Impact on Non-Apis Hymenopteran Species. PloS ONE, vol. 5, no. 12, p. 1-16.

TEIXEIRA, EW., CHEN, Y., MESSAGE, D., PETTIS, J. and EVANS, JD., 2008. Virus infection in Brazilian honey bees. J Invertebr Pathol vol. 99, p. 117-119.

WARD, L., WAITE, R., BOONHAM, N., FISHER, T., PESCOD, K., THOMPSON, H., CHANTAWANNAKUL, P. and BROWN, M., 2007. First detection of Kashmir bee virus in the UK using real-time PCR. Apidologie, vol. 38, p. 181-190.

WILLIAMS, PH. and OSBORNE, JL., 2009. Bumblebee vulnerability and conservation world-wide. Apidologie, vol. 40, p. 367-387. 